\title{
Allometric growth of body components in crossbred ewe lambs fed increasing dietary concentrate levels
}

\section{Crescimento alométrico dos componentes corporais de borregas mestiças alimentadas com níveis crescentes de concentrado na dieta}

\author{
Lincoln Bremm Oliveiraㄹ ; Maria da Graça Morais²; Caroline Bertholini Ribeiro; \\ Andréa Roberto Duarte Lopes Souza ${ }^{3 *}$; Henrique Jorge Fernandes ${ }^{4}$; \\ Camila Celeste Brandão Ferreira Ítavo²; Gumercindo Loriano Franco ${ }^{2}$; \\ Catherine Cecília Walker ${ }^{1}$; Luis Carlos Vinhas Ítavo²
}

\begin{abstract}
This study aimed to evaluate the growth of body components in crossbred ewe lambs fed increasing levels of dietary concentrate and to determine the optimum level of supplementation for finishing ewe production. Thirty crossbred ( $1 / 2$ Pantaneira $\times 1 / 2$ Texel) wool ewe lambs fed Tifton 85 hay (Cynodon spp.) and different dietary concentrate levels (20,40,60, and 80\% DM basis) were selected for study. At the beginning of the study, six animals were slaughtered for determination of initial body composition. The remaining animals were slaughtered at approximately $48 \mathrm{~kg}$ live weight. The growth of body components in relation to body growth was estimated from the allometric model $\mathrm{BC}=\mathrm{a} \times(\mathrm{FBW})^{\mathrm{b}}$, where $\mathrm{BC}$ is body component weight, $\mathrm{a}$ and $\mathrm{b}$ are growth equation parameters, and $\mathrm{FBW}$ is fasted body weight. Carcass, muscle, bone, and gastrointestinal tract were late maturing $(\mathrm{b}<1, \mathrm{P}<0.01)$. Carcass and carcass fat growth was positively affected (linear, $\mathrm{P}<0.05$ ) by concentrate level. Total fat weight increased with increasing concentrate level $(\mathrm{P}<0.05)$. The addition of up to $60 \%$ concentrate in growing ewe lamb diets is recommended for production of carcasses with early deposition of muscle and fat. The addition of $20 \%$ concentrate in ewe lab diets is sufficient for production of carcasses with maximum deposition of muscle and no excess fat.
\end{abstract}

Key words: Allometric coefficient. Body composition. Lambs.

\section{Resumo}

Objetivou-se avaliar o crescimento dos componentes corporais de borregas mestiças alimentadas com níveis crescentes de concentrado na dieta e estabelecer o nível adequado de suplementação para produção de fêmeas para abate. Foram utilizadas 30 borregas lanadas, oriundas de cruzamentos com ovinos da raça Texel, alimentadas com feno de capim-Tifton 85 (Cynodon spp.) e quatro níveis de concentrado na dieta $(20,40,60$ e 80\%). No início do experimento foi realizado abate para determinação da composição corporal de seis borregas. Os demais foram abatidos com aproximadamente $48 \mathrm{~kg}$. Para o estudo do

\footnotetext{
${ }^{1}$ Discentes, Curso de Mestrado do Programa de Pós-Graduação em Ciência Animal, Faculdade de Medicina Veterinária e Zootecnia, Universidade Federal de Mato Grosso do Sul, UFMS, Campo Grande, MS, Brasil. E-mail: linconlbremm@gmail. com; cbr_calu@yahoo.com.br; catherinecwalker@hotmail.com

2 Profs., Departamento de Zootecnia, Faculdade de Medicina Veterinária e Zootecnia, UFMS, Campo Grande, MS, Brasil. E-mail: morais.mariazinha@gmail.com; camila.itavo@ufms.br; gumercindo.franco@ufms.br; luis.itavo@ufms.br

${ }^{3}$ Pesquisadora, Programa de Desenvolvimento Científico Regional, DCR/CNPq/FUNDECT, Departamento de Zootecnia da Faculdade de Medicina Veterinária e Zootecnia, UFMS, Campo Grande, MS, Brasil. E-mail: andreardl_dagher@yahoo.com.br

${ }^{4}$ Prof., Departamento de Zootecnia, UFMS, Aquidauana, MS, Brasil. E-mail: henrique.uems@hotmail.com

* Author for correspondence
} 
crescimento dos componentes em relação ao crescimento corporal dos animais foi utilizado o modelo $\mathrm{CC}=\mathrm{a} \times \mathrm{PCJ}^{\mathrm{b}}$, onde $\mathrm{CC}=$ peso do componente corporal; a e b parâmetros das equações de crescimento e PCJ = peso corporal em jejum. A carcaça, músculos, ossos e trato gastrintestinal foram classificados como componentes de crescimento precoce $(b<1 ; \mathrm{P}<0,01)$. Foi observado efeito linear positivo dos níveis de concentrado sobre o crescimento da carcaça e gordura da carcaça $(\mathrm{P}<0,05)$. A quantidade total de gordura aumentou com os níveis crescentes de inclusão de concentrado na dieta $(P<0,05)$. Recomenda-se a inclusão de $60 \%$ de concentrado na dieta de borregas em crescimento para produção de carcaças com precocidade para deposição de músculo e gordura. A inclusão de $20 \%$ de concentrado na dieta de borregas é o suficiente para produção de carcaças com máxima deposição de músculos e sem excesso de gordura.

Palavras-chave: Coeficiente alométrico. Composição corporal. Ovinos.

\section{Introduction}

In lamb finishing systems, optimum slaughter weight must be achieved early to optimize productive performance. Even though male lambs are the most traded livestock in sheep farms, the contribution of ewe lambs in slaughter lots should also be taken into account by the lamb industry, as they are also slaughtered after their contribution to the breeding herd is over. As the growth of the several body components (bone, muscle, fat, organs, limbs, blood, skin, and viscera) affects body composition and carcass yield of ewe lambs (MALHADO et al., 2008), understanding it is essential for the development of feeding programs and to help determine optimum slaughter weight. During the growth and finishing phases, male and female lambs reach physiological maturity at different ages and weights, but the patterns of tissue deposition and organ growth curves are similar over time (MOHAMMADI et al., 2010).

Bone tissue and vital organs such as brain, eyes, lungs, kidneys, heart, esophagus, abomasum, and small intestine are well developed at birth, and thus grow at a slower rate after birth. Conversely, muscle and adipose tissue, which represent the main components of the carcass, are late maturing tissues (OWENS et al., 1993). Thus, slaughter age is affected by the allometric growth rates of each tissue and organ, which can be accelerated by improving management conditions and diet manipulation strategies to enable animals to express their full genetic growth potential.
In Brazil, few studies have investigated the growth and development of carcass components and the weights of internal organs in sheep, especially ewe lambs. Information regarding rates of growth of body components and carcass tissue weights is important for developing concentrate supplementation guidelines for increased productivity and quality of slaughter lamb carcasses.

This study aimed to evaluate the growth of body components in crossbred ewe lambs fed increasing levels of dietary concentrate and to determine the optimum level of supplementation for finishing ewe production.

\section{Material and Methods}

The study was conducted in the Animal Metabolism Laboratory at the Universidade Federal do Mato Grosso do Sul (UFMS) Faculty of Veterinary Medicine and Animal Science, in Campo Grande, MS, Brazil. Use and care of the animals in this study were approved by the UFMS Institutional Animal Care and Use Committee (process No. 235/2009).

Thirty crossbred ( $1 / 2$ Pantaneira $+1 / 2$ Texel) wool ewe lambs with initial body weight of $24.6 \pm 3.67$ $\mathrm{kg}$ and initial age of $3.0 \pm 1.0$ months were selected for study. Ewe lambs were randomly assigned to one of four dietary treatments $(20,40,60$, and $80 \%$ concentrate on a DM basis) with six animals per treatment, totaling 24 animals. Diets (Table 1) 
were formulated according to the National Research 2007), for a weight gain of 100, 150, 200, or $250 \mathrm{~g} /$ Council Nutrient Requirements for Sheep (NRC, day, respectively.

Table 1. Chemical composition of the experimental diets and ingredients, based on dry matter.

\begin{tabular}{|c|c|c|c|c|}
\hline \multirow{2}{*}{ Components } & \multicolumn{4}{|c|}{ Ingredients $\left(\mathrm{g} \mathrm{kg}^{-1} \mathrm{DM}\right)^{1}$} \\
\hline & Tifton 85 hay & Concentrate $^{2}$ & Urea & Mineral supplement $^{3}$ \\
\hline $\mathrm{DM}\left(\mathrm{g} \mathrm{kg}^{-1}\right)$ & 923.9 & 903.8 & 980.0 & 987.0 \\
\hline $\mathrm{OM}\left(\mathrm{g} \mathrm{kg}^{-1} \mathrm{DM}\right)$ & 937.7 & 940.5 & - & - \\
\hline $\mathrm{CP}\left(\mathrm{g} \mathrm{kg}^{-1} \mathrm{DM}\right)$ & 106.5 & 278.8 & 2.820 & - \\
\hline $\mathrm{EE}\left(\mathrm{g} \mathrm{kg}^{-1} \mathrm{DM}\right)$ & 23.3 & 28.7 & - & - \\
\hline NDFp (g kg-1 DM) & 769.7 & 304.2 & - & - \\
\hline $\operatorname{Lignin}\left(\mathrm{g} \mathrm{kg}^{-1} \mathrm{DM}\right)$ & 52.0 & 4.6 & - & - \\
\hline $\mathrm{NFC}^{4}\left(\mathrm{~g} \mathrm{~kg}^{-1} \mathrm{DM}\right)$ & 36.9 & 355.4 & - & - \\
\hline $\mathrm{Ca}\left(\mathrm{g} \mathrm{kg}^{-1} \mathrm{DM}\right)$ & 3.26 & 8.70 & - & 146.49 \\
\hline $\mathrm{P}\left(\mathrm{g} \mathrm{kg}^{-1} \mathrm{DM}\right)$ & 2.04 & 4.65 & - & 94.47 \\
\hline $\mathrm{Mg}\left(\mathrm{g} \mathrm{kg}^{-1} \mathrm{DM}\right)$ & 2.03 & 1.99 & - & 12.10 \\
\hline \multirow{2}{*}{ Components } & \multicolumn{4}{|c|}{ Forage:concentrate ratio } \\
\hline & $80: 20$ & $60: 40$ & $40: 60$ & $20: 80$ \\
\hline $\mathrm{DM}\left(\mathrm{g} \mathrm{kg}^{-1}\right)$ & 919.8 & 915.8 & 911.8 & 907.8 \\
\hline $\mathrm{OM}\left(\mathrm{g} \mathrm{kg}^{-1} \mathrm{DM}\right)$ & 938.3 & 938.8 & 939.4 & 939.9 \\
\hline $\mathrm{CP}\left(\mathrm{g} \mathrm{kg}^{-1} \mathrm{DM}\right)$ & 202.3 & 209.2 & 216.1 & 223.1 \\
\hline $\mathrm{EE}\left(\mathrm{g} \mathrm{kg}^{-1} \mathrm{DM}\right)$ & 24.4 & 25.4 & 26.5 & 27.6 \\
\hline $\operatorname{NDFp}\left(\mathrm{g} \mathrm{kg}^{-1} \mathrm{DM}\right)$ & 676.6 & 583.5 & 490.4 & 397.3 \\
\hline $\operatorname{Lignin}\left(\mathrm{g} \mathrm{kg}^{-1} \mathrm{DM}\right)$ & 42.5 & 33.0 & 23.6 & 14.1 \\
\hline $\mathrm{NFC}\left(\mathrm{g} \mathrm{kg}^{-1} \mathrm{DM}\right)$ & 100.6 & 164.3 & 228.0 & 291.7 \\
\hline $\mathrm{Fe}\left(\mathrm{mg} \mathrm{kg}^{-1} \mathrm{DM}\right)$ & 191.2 & 158.8 & - & 3.847 \\
\hline $\mathrm{Mn}\left(\mathrm{mg} \mathrm{kg}^{-1} \mathrm{DM}\right)$ & 81.0 & 51.1 & - & 969.0 \\
\hline $\mathrm{Zn}\left(\mathrm{mg} \mathrm{kg}{ }^{-1} \mathrm{DM}\right)$ & 33.5 & 80.0 & - & 1.599 \\
\hline $\mathrm{Cu}\left(\mathrm{mg} \mathrm{kg}^{-1} \mathrm{DM}\right)$ & 5.15 & 12.7 & - & 209.9 \\
\hline
\end{tabular}

${ }^{1}$ Dry matter express in $\mathrm{g} . \mathrm{kg}^{-1}$ and other components in $\mathrm{g} \mathrm{kg}^{-1}$ of DM.

${ }^{2}$ Ingredients: was ground corn, soybean meal, dry brewer's yeast, powdered sugar cane molasses, vitamin-mineral premix, dicalcium phosphate, calcium carbonate, sodium bicarbonate and urea.

${ }^{3}$ Estimated by equation of Hall (2000): NFC $=100-[(\mathrm{CP}-\mathrm{CP}$ derived from urea + urea $)+\mathrm{NDFp}+\mathrm{EE}+\mathrm{ash}]$; NFC $=$ non-fiber carbohydrate; $\mathrm{CP}=$ crude protein; $\mathrm{NDFp}=$ neutral detergent fiber corrected for protein; $\mathrm{EE} \%=$ ether extract.

Six additional animals were slaughtered for determination of initial body composition after a 28-day adaptation period. The ewe lambs were fed Tifton 85 hay, a hybrid of Bermuda grass (Cynodon dactylon), ground in a 1-cm sieve, and concentrate supplement. Urea was added to the 20,40 , and $60 \%$ concentrate diets at $2.36,1.57$, and 0.79 g.animal ${ }^{-1}$.day ${ }^{-1}$, respectively. Fresh water and mineral salt were available for ad libitum consumption throughout the study.

Before slaughter, ewe lamb body weight was recorded, after 16-h solids fasting. All animals were slaughtered when those in the $80 \%$ concentrate diet reached a fasted body weight (FBW) of $48 \mathrm{~kg}$ (after 100 days of diet treatment), for evaluation of final body composition. Slaughter procedures consisted of stunning the animals by concussion with a captive 
bolt pistol, followed by exsanguination, skinning, evisceration, and separation of the head and limbs. Then, the internal organs (heart, lungs/trachea/ esophagus, tongue, spleen, liver and gall bladder, kidneys, and reproductive system, bladder and udder), empty gastrointestinal (GI) tract components (rumen and reticulum, omasum, abomasum, large intestine, and small intestine), renal fat, omental and mesenteric fat, head, feet, and leather (skin and wool) were weighed separately.

Empty body weight (EBW) was calculated from the sum of all body components. Total organ weight was calculated as the sum of lungs, heart, liver, spleen, and kidneys. Total fat weight was calculated as the sum of intestinal, mesenteric, renal, and carcass dressing fat. The carcass of each animal was weighed immediately after slaughter and stored in a cold room at $4{ }^{\circ} \mathrm{C}$ for $24 \mathrm{~h}$. Next, the carcasses were halved and weighed. The left half-carcass was dissected for determination of bone, muscle and fat weight $(\mathrm{kg})$.

The growth of body components was estimated from an allometric model:

$$
\mathrm{BC}=\mathrm{a} \times(\mathrm{FBW})^{\mathrm{b}} \quad \text { Eq. [1], }
$$

where $\mathrm{BC}$ is body component weight $(\mathrm{kg})$, a and $\mathrm{b}$ are parameters of the allometric growth equations, and FBW is fasted body weight $(\mathrm{kg})$. In this model, parameter " $b$ " is the allometric coefficient and represents the relative growth rate of a given body component in relation to the entire body. Thus, a "b" value less than 1.0 indicates that the growth of a given component was smaller than the growth of the body (negative allometry); a " $b$ " value of 1.0 indicates that the body component grew at the same rate as the body (isometry), and a "b" value greater than 1.0 indicates that the body component grew at a faster rate than the average growth rate of the body (positive allometry).

The adjustment of allometric growth models and the estimation of parameters were conducted using the (PROC) NLIN procedure in SAS software version 9.2 (SAS, 2009). Outliers were detected by testing the studentized residuals against the values predicted by the model. Data were removed if the studentized residuals were outside the $-2.5-2.5$ range. Predictive growth models for each body component were compared between dietary treatments using a dummy variable (REGAZZI, 2003). The same methodology was used to determine whether allometric coefficients (parameter "b", Eq. [1]) were significantly different from 1.0. When a significant effect of concentrate level on the growth rate of a given body component was detected, the linear or quadratic effect of concentrate level on the allometric coefficient estimated for that body component was calculated using the (PROC) GLM procedure in SAS (SAS, 2009). P values $<0.05$ were considered significant.

\section{Results and Discussion}

Carcass and carcass fat allometric coefficients were positive (Table 2). The growth of carcass and carcass muscle and fat in ewe lambs was significantly affected by concentrate levels $(\mathrm{P}<0.01)$. Body components with positive allometric coefficients $(b>1)$ are considered late maturing, because they are still in the rapid growth phase. This result was expected because ewe lambs fed high-concentrate diets have better performance (RIBEIRO, 2011) and higher carcass yields (CACERE et al., 2014).

The higher energy content in the highconcentrate diet enable ewe lambs to express their full genetic growth potential and have rapid rates of body protein deposition, resulting in early lean deposition and increased body fat deposition (NRC, 2007). Accordingly, in the current study, ewe lambs fed an $80 \%$ concentrate diet had greater EBW and twice the fat content $(9 \mathrm{~kg}$ ) of ewe lambs fed a $20 \%$ concentrate diet (Table 3), and carcass bone and lean allometric coefficients were negative $(b<1.0$; Table 2), indicating early maturation of tissues. Bone and muscle have first priority in nutrient utilization during carcass growth, because they are 
weight-bearing components that occur in greater proportions in relation to the body, especially at birth. Cacere et al. (2014) evaluated quantitative and qualitative carcass traits in ewe lambs of the current study and reported hot carcass weights of $15.83,19.03,22.0$ and $24.93 \mathrm{~kg}$, and back fat depths of 2.24, 3.78, 5.46 and $7.41 \mathrm{~mm}$, for animals fed 20, 40,60 , and $80 \%$ concentrate diets, respectively (P $<0.05)$. The authors reported that supplementation with $20 \%$ dietary concentrate provided carcasses enough fat cover, as long as they reached more than $39 \mathrm{~kg}$ live weight.

Table 2. Parameters of the allometric equation for carcass growth, effect of concentrate level on growth (ECG), and linear (LEAC) and quadratic (QEAC) effect on the allometric coefficient.

\begin{tabular}{|c|c|c|c|c|c|c|c|c|}
\hline \multirow{2}{*}{ Parameter } & \multicolumn{4}{|c|}{ Concentrate level } & \multicolumn{4}{|c|}{ P value } \\
\hline & $20 \%$ & $40 \%$ & $60 \%$ & $80 \%$ & Allometry $\neq 1.0$ & ECG & LEAC & QEAC \\
\hline \multicolumn{9}{|c|}{ Carcass } \\
\hline $\mathrm{a}$ & 0.456 & 0.424 & 0.364 & 0.379 & & & & \\
\hline $\mathrm{b}$ & 1.025 & 1.048 & 1.111 & 1.098 & $<0.01$ & $<0.01$ & 0.103 & 0.609 \\
\hline \multicolumn{9}{|c|}{ Carcass fat } \\
\hline $\mathrm{a}$ & 0.010 & 0.006 & 0.004 & 0.008 & & & & \\
\hline $\mathrm{b}$ & 1.758 & 1.928 & 2.066 & 1.891 & $<0.01$ & 0.05 & n.a & n.a \\
\hline \multicolumn{9}{|c|}{ Carcass muscle } \\
\hline $\mathrm{a}$ & 0.386 & 0.449 & 0.429 & 0.478 & & & & \\
\hline $\mathrm{b}$ & 0.909 & 0.855 & 0.877 & 0.838 & $<0.01$ & $<0.01$ & 0.196 & 0.846 \\
\hline \multicolumn{9}{|c|}{ Carcass bone } \\
\hline $\mathrm{a}$ & 0.680 & 0.255 & 0.338 & 0.300 & & & & \\
\hline $\mathrm{b}$ & 0.276 & 0.669 & 0.547 & 0.593 & $<0.01$ & 0.064 & n.a & n.a \\
\hline
\end{tabular}

n.a: not analyzed.

As animals approach their mature weight and reach physiological maturity, protein deposition declines and adipose tissue deposition increases, i.e., the order of tissue development (bone $>$ muscle $>$ fat) does not change over time. However, tissue maturation rates are affected by various factors, including genotype and nutritional management (OWENS et al., 1993). The ewe lambs used in the current study were Texel crossbred lambs, which reach a mature weight of approximately $37 \mathrm{~kg}$ (MALHADO et al., 2008), and this weight has been observed in animals fed a $20 \%$ concentrate diet.

Table 3. Empty body weight (EBW) and fat, muscle, and bone weights, coefficient of variation (CV), and linear and quadratic effect of dietary concentrate levels in ewe lambs.

\begin{tabular}{lccccccc}
\hline \multirow{2}{*}{ Variable } & \multicolumn{9}{c}{ Concentrate level } & \multirow{2}{*}{ CV (\%) } & \multicolumn{2}{c}{ P value } \\
\cline { 2 - 4 } \cline { 7 - 8 } & 20 & \multicolumn{9}{c}{60} & \multicolumn{2}{c}{80} & & Linear & Quadratic \\
\hline EBW & $39.2 \pm 1.5$ & $42.7 \pm 1.9$ & $47.1 \pm 1.7$ & $48.7 \pm 2.1$ & 4.1 & $<0.0001$ & 0.214 \\
Fat & $9.9 \pm 1.4$ & $13.8 \pm 2.1$ & $17.2 \pm 2.4$ & $19.6 \pm 1.9$ & 12.8 & $<0.0001$ & 0.379 \\
Muscle & $22.3 \pm 1.2$ & $22.9 \pm 1.6$ & $23.9 \pm 1.4$ & $23.2 \pm 2.2$ & 7.1 & 0.234 & 0.334 \\
Bone & $6.9 \pm 2.5$ & $5.9 \pm 0.8$ & $5.9 \pm 0.7$ & $5.8 \pm 0.6$ & 22.6 & 0.199 & 0.467 \\
\hline
\end{tabular}


The lack of change in weight of bone and muscle over the range of concentrate levels $(\mathrm{P}>0.05$; Table 3) also indicates that ewe lambs had already reached physiological maturity, even with low-concentrate diets. When energy demands for maintenance and protein synthesis in adult animals are met, the body starts to use excess energy for fat deposition (NRC, 2007). Rosa et al. (2005) evaluated the allometric growth of bone, muscle, and fat in Texel lamb carcass cuts and reported similar allometric coefficients for fat growth (1.8-2.12). The allometric coefficients for head, limbs, and GI tract were negative $(b<1)$, consistent with them being early maturing tissues (Table 4).

At birth, limb and head size is approximately $60 \%$ that of mature animals, because these structures are key to support the body and protect the nervous system (OWENS et al., 1993). After birth, the development of these components continues in the rapid phase, but the increase in deposition rates to achieve mature weight depends on adequate energy intake to meet the maintenance and weightgain requirements that enable animals to express their full genetic growth potential. The weights of the head and limbs were significantly affected by concentrate level $(\mathrm{P}<0.01)$.

Other organs, such as the GI tract, mature early to increase feed utilization efficiency, as was observed in the current study $(b<1)$. GI tract weight was inversely related to concentrate level ( $P$ $<0.05$ ), which may be related to the composition of experimental diets (Table 1). Low-concentrate diets had higher fiber content and lower digestibility, which increase retention times, requiring greater development, and thus greater weight, of the GI tract.

Table 4. Parameters of the allometric equation for body parts growth, effect of concentrate level on growth (ECG), and linear (LEAC) and quadratic (QEAC) effect on the allometric coefficient.

\begin{tabular}{|c|c|c|c|c|c|c|c|c|}
\hline \multirow{2}{*}{ Parameter } & \multicolumn{4}{|c|}{ Concentrate level } & \multicolumn{4}{|c|}{ P value } \\
\hline & $20 \%$ & $40 \%$ & $60 \%$ & $80 \%$ & Allometry $\neq 1.0$ & ECG & LEAC & QEAC \\
\hline \multicolumn{9}{|c|}{ Head } \\
\hline $\mathrm{a}$ & 0.363 & 0.349 & 0.357 & 0.366 & & & & \\
\hline $\mathrm{b}$ & 0.358 & 0.370 & 0.363 & 0.355 & $<0.01$ & $<0.01$ & 0.272 & 0.254 \\
\hline \multicolumn{9}{|c|}{ Limbs } \\
\hline a & 0.066 & 0.084 & 0.092 & 0.088 & & & & \\
\hline $\mathrm{b}$ & 0.698 & 0.609 & 0.576 & 0.593 & $<0.01$ & $<0.01$ & 0.177 & 0.115 \\
\hline \multicolumn{9}{|c|}{ Gastrointestinal tract } \\
\hline $\mathrm{a}$ & 0.347 & 0.489 & 0.542 & 0.602 & & & & \\
\hline $\mathrm{b}$ & 0.517 & 0.382 & 0.346 & 0.306 & $<0.01$ & $<0.01$ & 0.193 & 0.285 \\
\hline \multicolumn{9}{|c|}{ Skin } \\
\hline $\mathrm{a}$ & 0.029 & 0.034 & 0.057 & 0.035 & & & & \\
\hline $\mathrm{b}$ & 1.344 & 1.272 & 1.097 & 1.253 & $<0.01$ & $<0.01$ & 0.443 & 0.450 \\
\hline \multicolumn{9}{|c|}{ Wool } \\
\hline $\mathrm{a}$ & 0.015 & 0.019 & 0.031 & 0.053 & & & & \\
\hline $\mathrm{b}$ & 1.437 & 1.333 & 1.162 & 0.990 & $<0.01$ & 0.016 & 0.006 & 0.265 \\
\hline
\end{tabular}

With the early development of head, limbs, and GI tract (Table 4), late maturing tissues started to develop more rapidly as concentrate levels were increased. Thus, when mature weight was reached, there was a deceleration and reduction in their proportions in relation to total body weight, increasing the relative contribution of late maturing tissues $(\mathrm{P}<0.05$; Table 5). 
Skin and wool were late maturing $(\mathrm{b}>1)$ and their allometric coefficients were significantly and inversely related to concentrate level $(\mathrm{P}<0.01)$. The increase in dietary nutrient concentration accelerated the growth of these components, which was likely required to meet the demands of the heavier, larger high-performance animals (RIBEIRO, 2011). Skin weight was positively affected by concentrate level
$(\mathrm{P}<0.05)$. Skin growth depends on the increase in body surface area, which in turns depends on the deposition of fat and muscle mass (Table 2). Conversely, the amount of wool produced was not affected by concentrate level $(\mathrm{P}>0.05)$. Body organs - tongue + trachea + esophagus + lungs, kidneys and liver + gallbladder + diaphragm - were early maturing ( $<<1$; Table 6$)$.

Table 5. Final weights non-carcass components, coefficient of variation (CV), and linear and quadratic effect of dietary concentrate levels in ewe lambs.

\begin{tabular}{|c|c|c|c|c|c|c|c|c|c|c|c|c|c|c|c|}
\hline \multirow{2}{*}{ Variable } & \multicolumn{11}{|c|}{ Concentrate level } & & \multirow{2}{*}{ CV (\%) } & \multicolumn{2}{|c|}{ P value } \\
\hline & \multicolumn{4}{|c|}{20} & \multicolumn{2}{|c|}{40} & \multicolumn{3}{|c|}{60} & \multicolumn{3}{|c|}{80} & & Linear & Quadratic \\
\hline \multicolumn{16}{|c|}{ Weight (kg) } \\
\hline Head & 3.3 & \pm & 0.3 & 3.3 & \pm & 0.2 & 3.0 & \pm & 0.1 & 2.9 & \pm & 0.2 & 6.3 & 0.0004 & 0.687 \\
\hline Limbs & 1.9 & \pm & 0.1 & 1.8 & \pm & 0.1 & 1.7 & \pm & 0.1 & 1.7 & \pm & 0.1 & 5.7 & 0.001 & 0.592 \\
\hline GI & 5.4 & \pm & 0.5 & 4.7 & \pm & 0.5 & 4.3 & \pm & 0.4 & 3.9 & \pm & 0.3 & 8.9 & $<0.0001$ & 0.307 \\
\hline Skin & 7.1 & \pm & 0.3 & 7.5 & \pm & 0.5 & 7.0 & \pm & 0.4 & 8.0 & \pm & 0.6 & 7.4 & 0.035 & 0.236 \\
\hline Wool & 5.3 & \pm & 1.2 & 5.2 & \pm & 0.9 & 4.7 & \pm & 1.2 & 4.5 & \pm & 1.9 & 27.7 & 0.253 & 0.867 \\
\hline
\end{tabular}

GI - Gastrointestinal tract

Table 6. Parameters of the allometric equation for total and individual of organs growth, effect of concentrate level on growth (ECG), and linear (LEAC) and quadratic (QEAC) effect on the allometric coefficient.

\begin{tabular}{|c|c|c|c|c|c|c|c|c|}
\hline \multirow{2}{*}{ Parameters } & \multicolumn{4}{|c|}{ Concentrate level } & \multicolumn{4}{|c|}{ P value } \\
\hline & $20 \%$ & $40 \%$ & $60 \%$ & $80 \%$ & Allometry $\neq 1.0$ & ECG & LEAC & QEAC \\
\hline \multicolumn{9}{|c|}{ Total of organs } \\
\hline $\mathrm{a}$ & 0.203 & 0.134 & 0.207 & 0.184 & & & & \\
\hline $\mathrm{b}$ & 0.757 & 0.929 & 0.754 & 0.791 & $<0.01$ & 0.035 & 0.887 & 0.686 \\
\hline \multicolumn{9}{|c|}{ Tongue + Trachea + Esophagus + Lungs } \\
\hline $\mathrm{a}$ & 0.059 & 0.077 & 0.069 & 0.078 & & & & \\
\hline $\mathrm{b}$ & 0.709 & 0.622 & 0.663 & 0.616 & $<0.01$ & $<0.01$ & 0.290 & 0.742 \\
\hline \multicolumn{9}{|c|}{ Kidneys } \\
\hline $\mathrm{a}$ & 0.009 & 0.012 & 0.010 & 0.009 & & & & \\
\hline $\mathrm{b}$ & 0.668 & 0.581 & 0.642 & 0.671 & $<0.01$ & $<0.01$ & 0.780 & 0.389 \\
\hline \multicolumn{9}{|c|}{ Spleen } \\
\hline $\mathrm{a}$ & 0.002 & 0.002 & 0.003 & 0.003 & & & & \\
\hline $\mathrm{b}$ & 0.989 & 0.913 & 0.868 & 0.938 & $<0.01$ & 0.222 & n.a. & n.a. \\
\hline \multicolumn{9}{|c|}{ Liver + Gallbladder + Diaphragm } \\
\hline $\mathrm{a}$ & 0.024 & 0.023 & 0.019 & 0.018 & & & & \\
\hline $\mathrm{b}$ & 0.918 & 0.930 & 0.978 & 1.022 & $<0.01$ & $<0.01$ & 0.025 & 0.315 \\
\hline \multicolumn{9}{|c|}{ Heart } \\
\hline $\mathrm{a}$ & 0.019 & 0.018 & 0.014 & 0.009 & & & & \\
\hline $\mathrm{b}$ & 0.525 & 0.544 & 0.651 & 0.784 & $<0.01$ & 0.43 & n.a. & n.a. \\
\hline
\end{tabular}

n.a: not analyzed. 
Allometric coefficients for body organs were positively affected by concentrate level $(\mathrm{P}<0.01)$, with the exception of heart and spleen $(\mathrm{P}>0.05)$. This result may be due to the higher performance and greater body weight of ewe lambs, which required greater control of nutrient distribution (liver) to tissues and increased excretion of toxic metabolites (kidneys) in urine. Conversely, tongue + trachea + esophagus + lungs allometric coefficients were inversely related to concentrate level $(\mathrm{P}<0.01)$. This result can be explained by the fact that tongue + trachea + esophagus + lungs weight was not significantly affected by concentrate level (Table 7).
The liver + gall bladder + diaphragm had allometric coefficients $>1.0(\mathrm{P}<0.01)$, indicating that these organs were late maturing. Liver growth accelerated gradually as nutrient concentration increased with increasing concentrate level, from null to late maturation ("b" value close to 1.0 up to values $>1.0$, respectively). The liver is the main site involved in the control and distribution of nutrients for use in visceral and intermediary metabolism and contributes to improve feed efficiency (ALLEN et al., 2009). Liver growth was dependent on the availability of energy and the metabolic demands of the animal, resulting in late liver maturation. In fact, liver growth was related to dietary energy level, because liver weight increased significantly with increasing concentrate level (Table 7).

Table 7. Final weights of organs, coefficient of variation (CV), and linear and quadratic effect of dietary concentrate levels in ewe lambs.

\begin{tabular}{|c|c|c|c|c|c|c|c|c|c|c|c|c|c|c|c|}
\hline \multirow{2}{*}{ Variable } & \multicolumn{12}{|c|}{ Concentrate level } & \multirow{2}{*}{$\begin{array}{l}\text { CV } \\
(\%)\end{array}$} & \multicolumn{2}{|c|}{$\mathrm{P}$ value } \\
\hline & & 20 & & & 40 & & & 60 & & & 80 & & & Linear & Quadratic \\
\hline \multicolumn{16}{|c|}{ Organs (kg) } \\
\hline Total & 7.1 & \pm & 0.4 & 9.1 & \pm & 3.8 & 7.3 & \pm & 0.4 & 7.4 & \pm & 0.4 & 25.6 & 0.828 & 0.249 \\
\hline $\begin{array}{l}\text { Tongue }+ \text { Trachea }+ \\
\text { Esophagus }+ \text { Lungs }\end{array}$ & 1.7 & \pm & 0.18 & 1.7 & \pm & 0.22 & 1.8 & \pm & 0.23 & 1.6 & \pm & 0.13 & 11.4 & 0.328 & 0.428 \\
\hline Kidneys & 0.2 & \pm & 0.01 & 0.2 & \pm & 0.02 & 0.2 & \pm & 0.01 & 0.3 & \pm & 0.02 & 6.9 & 0.993 & 0.285 \\
\hline Spleen & 0.2 & \pm & 0.01 & 0.2 & \pm & 0.02 & 0.2 & \pm & 0.03 & 0.2 & \pm & 0.04 & 18.8 & 0.157 & 0.388 \\
\hline $\begin{array}{l}\text { Liver + Gallbladder } \\
+ \text { Diaphragm }\end{array}$ & 1.4 & \pm & 0.07 & 1.5 & \pm & 0.14 & 1.5 & \pm & 0.13 & 1.7 & \pm & 0.13 & 8.2 & 0.005 & 0.663 \\
\hline Heart & 0.3 & \pm & 0.05 & 0.3 & \pm & 0.03 & 0.3 & \pm & 0.04 & 0.4 & \pm & 0.05 & 13.2 & 0.008 & 0.187 \\
\hline
\end{tabular}

Heart weight increased (linear, $\mathrm{P}<0.05$ ) with increasing concentrate level. Because of the increase in body weight and the growing maintenance requirements, the animal requires a larger heart to improve blood flow and meet the increased demand for oxygen and nutrients from tissues. In fact, EBW was 30\% greater in ewe lambs fed an $80 \%$ concentrate diet than in ewe lambs fed a $20 \%$ concentrate diet (Table 3), and the hearts of the former were $100 \mathrm{~g}$ heavier. However, kidney, spleen, and body organ weights were not significantly affected by concentrate level (P >0.05; Table 7).

Considering the allometric growth coefficients and the weights of carcass tissues, the addition of $40 \%$ concentrate promoted maximum muscle tissue growth, whereas higher supplementation levels resulted in growth deceleration; for fat, a similar pattern was observed in ewe lambs fed 60 and $80 \%$ concentrate diets (Table 2). These results reflected on the final empty body and carcass 
weights and indicated that, at $39 \mathrm{~kg}$ live weight (the weight achieved by animals fed a $20 \%$ concentrate diet (Table 3), the ewe lambs had already reached physiological maturity and further addition of concentrate only resulted in significant increases in body fat. This result indicates that investing in high-concentrate diets for ewe lambs close to maturity is disadvantageous because any excess fat deposited in the carcass is discarded at processing, which may reduce carcass value or attract price penalties at retail. Thus, high-concentrate diets may be recommended for ewe lambs close to maturity only when the goal is to accelerate growth rates to achieve minimum slaughter weights earlier and reduce finishing times.

The only late maturing organs were liver + gall bladder + diaphragm, which may have had to meet the increased metabolic demands of highconcentrate diets. The effects of high-concentrate diets were not beneficial, because ewe lambs offered the $80 \%$ concentrate diet had lower dry matter digestibility (RIBEIRO, 2011) and a 50\% increase in body fat content, which in excess is undesirable for the marketing of meat cuts.

\section{Conclusion}

The addition of up to $60 \%$ concentrate in growing ewe lamb diets is recommended for production of carcasses with early deposition of muscle and fat.

The addition of $20 \%$ concentrate in ewe lamb diets is sufficient for production of carcasses with maximum deposition of muscle and no excess fat.

\section{Acknowledgements}

We thank the Fundação de Apoio ao Desenvolvimento do Ensino, Ciência e Tecnologia from the state of Mato Grosso do Sul, Brazil, for financial support.

\section{References}

ALLEN, M. S.; BRADFORRD, B. J.; OBA, M. BOARDINVITED. Review: the hepatic oxidation theory of the control of feed intake and its application to ruminants. Journal of Animal Science, Savoy, v. 87, n. 10, p. 33173334, 2009.

CACERE, R. A. S.; MORAIS, M. G.; ALVES, F. V.; FEIJÓ, G. L. D.; ÍTAVO, C. C. B. F.; OLIVEIRA, L. B.; RIBEIRO, C. B. Quantitative and qualitative carcass characteristics of feedlot ewes subjected to increasing levels of concentrate in the diet. Arquivo Brasileiro de Medicina Veterinária e Zootecnia, Belo Horizonte, v. 66, n. 5, p. 1601-1610, 2014.

HALL, M. B. Calculation of non-structural carbohydrate content of feeds that contain non-protein nitrogen. Gainesville: University of Florida, 2000. 77 p. (Bulletin, 339).

MALHADO, C. H. M.; CARNEIRO, P. L. S.; SANTOS, P. F.; AZEVEDO, J. C. S.; AFFONSO, P. R. M. Curva de crescimento em ovinos mestiços Santa Inês x Texel criados no Sudoeste do Estado da Bahia. Revista Brasileira de Saúde e Produção Animal, Salvador, v. 9, n. 2, p. 210-218, 2008.

MOHAMMADI, K.; BEYGI NASSIRI, M. T.; FAYAZI, J.; ROSHANFEKR, H. Investigation of environmental factors influence on pré-weaning growth traits in Zandi lambs. Journal of Animal Veterinary Advances, Savoy, v. 9, n. 6, p. 1011-1014, 2010.

NATIONAL RESEARCH COUNCIL - NRC. Nutrients requirements of small ruminants. Washington: National Academy Press, 2007. 362 p.

OWENS, F. N.; DUBESKI, P.; HANSON, C. F. Factors that alter the growth and development of ruminants. Journal of Animal Science, Savoy, v. 71, n. 11, p. 31383150, 1993.

REGAZZI, A. J. Teste para verificar a igualdade de parâmetros e a identidade de modelos de regressão nãolinear. Revista Ceres, Viçosa, MG, v. 50, n. 3, p. 9-26, 2003.

RIBEIRO, C. B. Exigência proteica de fêmeas ovinas mestiças. 2011. Dissertação (Mestrado em Ciência Animal) - Universidade Federal de Mato Grosso do Sul, Campo Grande.

ROSA, G. T.; PIRES, C. C.; SILVA, J. H. S.; MULLER, L. Crescimento do osso, músculo e gordura dos cortes da carcaça de cordeiros e cordeiras em diferentes métodos de alimentação. Revista Brasileira de Zootecnia, Viçosa, MG, v. 31, n. 6, p. 2238-2289, 2005. 
STATISTICAL ANALYSIS SYSTEM INSTITUTE -

SAS Institute. Statistical Analysis System. SAS versão

9.2. Cary: SAS Inst. Inc., 2009. 